\title{
Food safety of bottled water
}

\author{
Marietta Shapsugova ${ }^{1, *}$ \\ ${ }^{1}$ Institute of State and Law, Russian Academy of Sciences, Russia
}

\begin{abstract}
Drinking water is a strategically important natural resource. At the same time, its resource is unevenly distributed over the territory of Russia. One way to redistribute drinking water resources is to bottle and then deliver it to scarce regions. The study's objectives are to identify gaps in the system of drinking water resource management in Russia. Particular attention is paid to the management of the quality of bottled water. The study showed that despite the strategic importance of drinking water for citizens' health, its quality is not managed at the systemic level. Bottled water is food, and, accordingly, its quality should be standardized for food safety. However, quality regulation is carried out non-systemically and fragmentarily. The identified problems also include the problem of identifying waters and the fight against counterfeit products. The methods of analysis and synthesis, induction and deduction, comparative method, statistical data were used.
\end{abstract}

\section{Introduction}

Rational usage of freshwater ecosystems and access to safe drinking water is vital for human health, environmental sustainability, and economic prosperity.

The problem of the quality of drinking bottled water is acute all over the world $[1,2,3]$.

The UN Sustainable Development Concept sets the goal of accessibility of clean water and sanitation for the population. This goal is of particular relevance in connection with the COVID -19 pandemic.

The provision of high-quality potable water is a form of realization of a person's rights to a healthy environment. The environment is favorable if its condition complies with the criteria, standards, norms established in the legislation on the environment, reflecting its purity (non-pollution ), resource intensity (inexhaustibility), ecological sustainability, species diversity, and aesthetic richness [4].

The majority of the Russian population still uses water for drinking and household needs that does not meet hygienic requirements and poses a real threat to its health. There is an uneven distribution of drinking water resources across the Russian Federation's territory [5]. Bottled water is one of the options for solving the problem of providing the population with standard quality drinking water. According to Russian legislation, bottled water is classified as a food (Federal Law "On the quality and safety of food products"). Therefore, requirements for the quality and safety of food products apply to it.

\footnotetext{
*Corresponding author: shapsugova@gmail.com
} 


\section{Methods}

Unequal allocation of drinking water due to both man-made (water pollution with industrial and household waste ) and natural factors: $84 \%$ of surface waters have to pools Arctic (3030 $\mathrm{km} 3$ / year) and Pacific Oceans (950 km3 / year). The largest rivers flow into them: the Yenisei, Lena, Ob, and Amur, which give $44 \%$ of the flow of all rivers. On Southern and Southwestern parts (Black Sea and Azov, Aral -Kaspiyskaya lowland) where focus $75 \%$ of the population and $80 \%$ of the industry and agricultural production, only $750 \mathrm{~km} 3$, or $16 \%$ of surface water resources. On the European territory of the country, the flow of rivers of the southern slope (Volga, Ural, Dnieper, Don, Kuban, Kura, Terek, etc.) is $605 \mathrm{~km} 3$, or 50\% of the river flow of this part of Russia [5].

Simultaneously, the volume of the bottled water market in Russia in 2019 amounted to 26.3 billion liters and increased by $28.9 \%$. In recent years, bottled water has become the fastest-growing segment in the beverage structure worldwide (According to a study by NeoAnalytics on the topic "Russian market of drinking and mineral water: results of 2019 , forecast until 2022").

\section{Results}

Given the strategic importance and scarcity of high-quality drinking water, the drinking water resource management system in Russia can be considered unsatisfactory.

More than a dozen executive authorities perform various functions in this area. However, the coordination of their activities is not carried out at all. Many different normative and recommendatory documents contradict each other. There is no uniform system of quality management and water safety as a strategic resource at all production stages: water intake, water treatment, the supply of centralized water supply systems, or bottling. The formation of the state function of integrated water resources management is of paramount importance. Although the territory of Russian freshwater resources are unevenly distributed [6], and legislative level is not fixed to drinking water's legal status as a scarce strategic resource. It is necessary to consider that quality regulation of drinking water should be comprehensive, affect the water as a substance, and environmentally related e questions.

\section{Discussion}

There have been several unsuccessful attempts to pass a law on drinking water in Russia. For example, the Federal Law "On Drinking Water and Drinking Water Supply" was adopted by the State Duma on December 1, 1999, but rejected by the Federation Council on December 23, 1999.

Despite the fundamental importance of drinking water for human health, there is no legislative definition in Russia. The EAEU technical regulations on packaged water also contain a non-exhaustive definition of drinking water and do not consider bottled water from central water supply networks. Simultaneously, bottled water can become an effective method of redistributing drinking water resources from wealthy regions to scarce ones.

The EU's approach to this issue should be recognized as more perfect. First of all, we are talking about Art. 2 Council Directive 98/83 / EC of 3 November 1998 "On the quality of water intended for human consumption", which defines the Concept of water intended for human consumption, regardless of the method of supply (distribution network, cistern, bottles, containers) [7].

One way to control the quality of drinking water is to identify water and check its compliance with the reference sample. Verification of such compliance allows avoiding the sale of falsified water [8]. Based on Decree of the Government of the Russian Federation of 
March 27, 2020 N 348 on the Russian Federation's territory from April 1 this year on March 1, 2021 experimented on the labeling means identification of packaged water. [9]

State regulation in the field of ensuring the quality of bottled water is carried out through state regulation, state registration of products, and conducting examinations [10, p. 125].

In the absence of a united management system of quality and safety of drinking water as a strategic resource at all stages of production (water intake, water treatment, the supply of centralized water supply systems or bottling), as well as difficulties encountered in this process, the drinking water legislation is interdisciplinary.

The use of waters that have lost the quality of natural good, being separated from the natural environment, and the application of labor to it is considered the use of commodity and material values. It is one of the grounds for applying civil legislation to the legal Regulation of providing the population with drinking water of standard quality, and based on paragraph 1 of Art. 2 of the Civil Code of the Russian Federation [10, p. 31-32]. The main block of norms is assigned to the norms of the institute of water use law, the purchase and sale of water in civil legislation, sanitary and environmental Regulation, and tax regulation $[10$, p. 41].

By Section 9 "Requirements for drinking water, packaged in containers" of the Unified Sanitary-Epidemiological and Hygienic Requirements for Products (Goods) Subject to Sanitary-Epidemiological Supervision (Control), approved by The decision of the Customs Union Commission dated May 28, 2010 N 299 provides for the classification of drinking water:

According to the water source (p. 3.1): from the underground water source (artesian, spring (key), ground (infiltration) and from the surface - river, lake, glacial;

By way of water treatment: from the water supply network (purified and further purified ) and condition.

Water intake based on Art. 5 of the Water Code of the Russian Federation) can be carried out from the surface and underground water bodies (natural surface and underground water source). Various federal laws determine the modes of protection zones of water bodies from which water intake is carried out: sanitary protection zones (Federal Law On the Sanitary and Epidemiological Welfare of the Population, Article 105 of the Land Code of the Russian Federation)), water protection zones of water bodies (Water Code of the Russian Federation), - sanitary) protection of resorts and health-improving areas (Federal Law On natural healing resources, health-improving areas, and resorts), zones of sanitary protection of water supply sources, protective forest belts along the banks of water bodies (Federal Law On Environmental Protection) (Forest Code).

The standards for the proper removal of components of the natural environment are provided for by Art. 26 FZ On Environmental Protection. Rationing in the field of the use and protection of water bodies provides for the establishment of water use limits (water consumption and disposal), the development and adoption of standards, norms, and rules in the field of use and protection of water bodies (Articles 82, 90, 110 of the VK RF, Resolution of the Government of the Russian Federation of December 30, 2006 N 844 "On the procedure for preparing and making a decision on the provision of a water body for use", Resolution of the Government of the Russian Federation dated March 12, 2008 N 165 "On the preparation and conclusion of a water use agreement").

Following clause 3 of the Decree of the Government of the Russian Federation of March 12, $2008 \mathrm{~N} 165$ "On the preparation and conclusion of a water use agreement." The preparation and conclusion of a water use agreement in the form of a model water use agreement approved by the Government of the Russian Federation dated March 12, $2008 \mathrm{~N}$ 165 , based on the appeal of a legal entity, individual or individual entrepreneur, is carried out depending on who owns the water body: Federal agency of water resources or its territorial 
bodies, the executive authority of the constituent entity of the Russian Federation, local government.

The intake of water from water bodies to meet the population's drinking needs with the use of structures, technical means, and devices (special water use) is regulated by Part 3 of Art. 86 Water Code of Russia and Art. 135 and Federal Law On Water Supply and Wastewater Disposal [10, p. 40].

The legal regime of surface waters is determined by the Water Code of the Russian Federation. Rosvodresrurs carry out the granting of the right to use water bodies under paragraph 4 of the Government Decree of April 6, 2004 N 169 "Issues of the Federal Agency for Water Resources". By Part 2 of Art. 11 of the Water Code of the Russian Federation, water intake from them is carried out based on water use agreements, the right to use surface water bodies that are in federal ownership, a property of the constituent entities of the Russian Federation, a property of municipalities.

The next element in the management of drinking water resources is the state supervision of the use and protection of water bodies, which is carried out by Rosprirodnadzor (clause 5.1.6 of the Decree of the Government of the Russian Federation of July 30, 2004 N 400 "On Approval of the Regulation on the Federal Service for Supervision of Natural Resources and amending the Resolution of the Government of the Russian Federation dated July 22, 2004 N 370").

The legal regime of groundwater is determined by the Federal Law "On Subsoil" Federal Agency for Subsoil Use (Rosnedra) Based on the positions of the I of the Federal Agency for Subsoil Use, approved. Decree of the Government of 17 June 2004 N 293, Rosnedra carry renditions have licenses for groundwater use as the subsoil (Sec. 5.3.8).

Underground mineral water can be produced with no restrictions other than industrial bottling, carried out by matching with Rosnedra.

Water intake of the centralized water supply system based on water supply contract (Art. 23 of the Federal Law of December 7, 2011 N 416-FZ "On the Water Supply and Sanitation")

Bottled drinking water is excluded from the scope of the Federal Law dated 07.12.2011 N 416-FZ (as amended on 01.04.2020) "On water supply and wastewater disposal" (Clause 18, Article 5).

Ensuring the quality of drinking water from the central water supply system is regulated by Art. 23, 25 FZ On water supply.

Requirements for water quality in centralized water supply systems are established by Sanitary and Epidemiological Rules and SanPiN 2.1.4.1074-01. "Drinking water. Hygienic requirements for water quality of centralized drinking water supply systems. Quality control. Hygienic Requirements for Ensuring Safety of Hot Water Supply Systems ".

By the Federal Law "On the Sanitary and Epidemiological Welfare of the Population", state sanitary and epidemiological supervision and production control should be carried out over the quality of drinking water (clause 4.1.)

According to the work program, production control of the quality of drinking water is provided by the business entity operating the water supply system (clause 4.2.). The quality of water is monitored at the points of water intake before entering the distribution network and at the points of water intake of the external and internal water supply network.

Water treatment is a process in the water, ensuring its use as drinking or industrial water (Art. 1 Federal Law of December 7, 2011 N 416-FZ "On the Water Supply and Sanitation").

For the production of bottled water (GOST 32220-2013 "drinking water, packaged in a container. Common specifications" sets the requirements for the raw water (Sec. 5.3.1). It depends on the type of used water surface or underground sources of drinking water and centralized drinking water supply systems (hereinafter referred to as source water).

Source water from a drinking water supply source must comply with the hygienic requirements established in GOST 2761 or GOST 2874, taking into account the national 
sanitary and epidemiological rules and norms in force in the field drinking and domestic drinking water supply.

According to the SanPiN 2.1.4.1074-01 established in the Sanitary and Epidemiological Rules and Regulations SanPiN 2.1.4.1074-01 "Drinking water. Hygienic requirements for water quality in centralized drinking water supply systems. Quality control. Hygienic requirements for ensuring the safety of hot water supply systems", the quality control of source water is carried out by the manufacturer according to indicators, in the amount and with the frequency corresponding to those established in GOST 2874, GOST 2761, taking into account the requirements of national regulatory (surface, water supply) sanitary and epidemiological rules and norms, hygienic standards for specific underground waters, centralized drinking water supply systems (p. 5.3.1.3).

Besides, requirements are established both for materials, reagents, equipment used for water purification and water treatment, and water quality requirements.

Sanitary requirements are determined by the Federal Law On Sanitary and Epidemiological Well-being of the Population, following which (sanitary norms and rules (SanPIN) is adopted), water quality management is regulated by the Federal Law On Technical Regulation (primarily Art. 23-25) and the adopted GOSTs and technical regulations. By Art. 23 of the Federal Law" On Technical Regulation" obligatory confirmation of conformity is provided only in cases established by technical regulations. In other cases, it is voluntary.

Until January 1, 2019, the state registration of water (mandatory confirmation) was carried out based on the List of products, for which a certificate of state registration is required. All types of packaged water were subject to state registration.

After the entry into force of the technical Regulation TR EAEU 044/2017 "On the safety of packaged drinking water, including natural mineral", state registration is applied to certain types of products.

Clause 53 of the EAEU TR 044/2017 regulation provides for two modes:

1. State registration of water (mandatory confirmation of conformity) for baby food, medical table, and healing natural mineral water.

2. Declaration of conformity (voluntary confirmation of conformity) for other types of waters (Article 23 of the Technical Regulations of the Customs Union TR CU 021/2011 "On food safety" (approved by the decision of the Commission of the Customs Union of December 9, 2011 N 880)

Currently, on the territory of the Customs Union countries, there is a Unified Register of accredited organizations entitled to research product images and certification.

By order of Rospotrebnadzor dated 20.07.2010 N 290 (as amended by order of Rospotrebnadzor dated 19.09.2011 N 742) "On state registration of products by territorial bodies", the authority to issue certificates of state registration for certain types of products was delegated to the departments of Rospotrebnadzor in the constituent entities of the Russian Federation.

Under clause 3.3. The Resolution I of the Chief State Sanitary Doctor of the Russian Federation of March 19, 2002 N 12 "On introduction of the sanitary-epidemiological rules and norms" Drinking water Hygienic requirements for water quality, packaged in a container. Quality control. SanPiN 2.1.4.1116-02"», depending on the quality of the water, improved to the hygienic requirements for the water of the centralized water supply (SanPiN 2.1.4.107401 ), as well as additional medical and biological requirements, the bottled water is divided into the water of the first and second categories.

The Federal Service performs the main functions of quality and safety management of bottled drinking water for Supervision of Consumer Rights Protection and Human Wellbeing, which is managed by the Government of the Russian Federation (Regulation on the 
Federal Service for Supervision of Consumer Rights Protection and Human Well-being, approved by Resolution Government of the Russian Federation dated June 30, 2004 N 322).

At the same time, by paragraph 8 of the Decree of the Government of the Russian Federation of March 27, 2020 N 348 "On conducting an experiment on labeling with identification means of packaged water in the territory of the Russian Federation ", the Ministry of Agriculture of the Russian Federation was instructed to ensure coordination and monitoring of the work of turnover participants packaged water participating in the experiment.

This function - coordination and monitoring of participants' work in the turnover of packed water - was not assigned to any public authority before the adoption of Resolution $\mathrm{N}$ 348.

Under Government Decree N 348, a new management function is being formed. Thus, vesting the Ministry of Agriculture with the appropriate powers does not conflict with the current distribution of powers between executive authorities.

Drinking water packaged in containers is classified as a food? according to Art. 4 of the Technical Regulations of the Customs Union TR CU 021/2011 "On food safety" (approved by the Customs Union's decision Commission of December 9, 2011 N 880). Uniform sanitary and epidemiological, and hygienic requirements for products (goods) subject to sanitary and epidemiological supervision (control) (approved by the decision of the Customs Union Commission of May 28, $2010 \mathrm{~N}$ 299) in clause 3 also refer to food products as bottled drinking water in a container (bottled drinking water).

In terms of marking with identification means, the Ministry of Agriculture is entrusted with the implementation of the state service for issuing an opinion attached to the application for state registration of an appellation of origin and for granting an exclusive right to such an appellation and in issuing an opinion attached to an application for granting an exclusive right to a previously registered appellation of place the origin of goods (Decree of 17.09.2004 "On the list of federal executive bodies competent to give an opinion attached to the application for state registration of an appellation of origin of goods and the granting of an exclusive right to such an appellation", Administrative regulations dated 09.04.2012 "Administrative regulations of the Ministry agriculture of the Russian Federation for the provision of public services for the issuance of an opinion attached to an application for state registration of an appellation of origin")

The provision of the population with drinking water is an element of food security (Decree of the President of the Russian Federation of January 21, 2020 N 20 "On approval of the Doctrine of food security of the Russian Federation")

The Ministry of Agriculture of the Russian Federation (Ministry of Agriculture of the Russian Federation) is a federal executive body performing functions (paragraph 2, clause 1 of the Regulation on the Ministry of Agriculture of the Russian Federation (approved by the Government of the Russian Federation of June 12, 2008 N 450) for the development of state policy and regulatory and legal Regulation in the field of the agro-industrial complex, including regulation of the market for agricultural products, raw materials and foodstuffs, food and processing industries.

Because bottled water is recognized as food and its products to the food industry, the implementation of the functions of coordination and monitoring of the participants' work turn packaged water is related to the activities of the Ministry of Agriculture as well. At the same time, in order to avoid uncertainty, it is proposed to supplement the first paragraph of the first clause of the first Regulation on the Ministry of Agriculture of the Russian Federation (approved by the Russian Government Decree of June 12, 2008 N 450 after the words "including regulation of the market of agricultural products, raw materials and food, food and processing industry, including "add the words" packaged water ". 
In the understanding of the Treaty on the Eurasian Economic Union, food and the formation of uniform requirements in the production and circulation of products are attributed to the agro-industrial complex and agro-industrial policy sphere.

Also, the Ministry of Agriculture has a sufficiently developed regional structure to implement the new powers.

Packaged water is not included in the List of agricultural products, production, the primary and subsequent (industrial) processing of which is carried out by agricultural producers, as well as scientific organizations, professional educational organizations, educational organizations of higher education in the course of their scientific, scientific and technical and (or) educational activities (approved by the order of the Government of the Russian Federation of January 25, 2017 N 79-r). In this connection, it should also be included in this List.

Simultaneously, taking into account the existing quality and safety management system for drinking water, coordination and monitoring of the work of participants in the circulation of packaged water could be carried out by Rospotrebnadzor .

Controlling bodies are federal executive authorities that, using the information monitoring system, carry out functions of control (supervision) in the sphere of circulation of goods subject to identification by means of identification (clause 10 of the Regulation on the state information system for monitoring the circulation of goods subject to mandatory identification, approved. Decree of the Government of the Russian Federation dated April 26, 2019 N 515)

So, in order to implement the Strategy for countering the illicit trafficking of industrial products in the Russian Federation for the period until 2020 and the planned period until 2025 and in accordance with the tasks defined by the Concept for the creation and operation of a system for marking goods in the Russian Federation by means of identification and traceability of goods movement (order of the Government of the Russian Federation of December 28, 2018 N 2963-r) in the manner prescribed by the Federal Law of December 26, 2008 N 294-FZ "On the protection of the rights of legal entities and individual entrepreneurs in the exercise of state control (supervision) and municipal control", by territorial bodies Rospotrebnadzor carries out inspections of economic entities selling goods to consumers that are subject to labeling with identification means, including products made from natural fur, in accordance with the Decree of the Government of the Russian Federation of 11.08.2016 N 787.

\section{Conclusion}

There is a problem of discrepancy between the level of the critical national strategic importance of the drinking water resource and the quality of its legal support.

The state management of strategic drinking water resources requires improvement. First of all, such management should be systemic.

One of the unregulated aspects, given the growth in bottled water production, is the problem of authenticity[11] standardization and control over its quality. Also, the fight against water counterfeiting is of paramount importance. These goals are served by the introduction of a system of marking and identification of waters.

It can be concluded that bottled drinking water will allow evenly redistributing drinking water resources, as well as reducing the loss of drinking water during its production, transportation, and, above all, consumption by households since the cost of bottled water significantly exceeds the cost of tap water, which contributes to its more rational use.

Besides, due to the urgency of the problem of providing the population with drinking water of standard quality, it is necessary to develop the Federal Law "On Drinking Water and Drinking Water Supply", in which the Concept of drinking water should be introduced, and 
its status as a strategic natural resource in order to ensure food security and the realization of human rights. for a favorable environment.

\section{References}

1. I. Lyne, Water Alternatives 13(3), 731-751 (2020)

2. N. Spicer, B. Parlee, M. Chisaakay, D. Lamalice, Sustainability 12(17), 6851(2020) https://doi.org/10.3390/su12176851

3. A. Gschwandtner, C. Jang, R. McManus, Water (Switzerland) 12(9), 2569 (2020) https://doi.org/10.3390/w12092569

4. M.M. Brinchuk, Environmental law (Jurist, M., 1998)

5. State report of the Ministry of Natural Resources and Ecology of the Russian Federation, http://www.mnr.gov.ru/docs/o_sostoyanii_i_ispolzovanii_vodnykh_resursov_rossiysko y_federatsii/gosudarstvennyy_doklad_o_sostoyanii_i_ispolzovanii_vodnykh_resursov _rossiyskoy_federatsii_v_2017_god/

6. Order of the Government of the Russian Federation of August 27, 2009 N 1235-r on the approval of the Water Strategy of the Russian Federation for the period up to 2020

7. L.A. Timofeev, Legal problems of providing the population of Russia with drinking water of standard quality: dissertation, doct. Of legal sciences (Saratov, 2004)

8. Council Directive 98/83 / EC of November 3, 1998 "On the quality of water intended for human consumption", http://base.garant.ru/2568523/\#ixzz6N6uxKGPz

9. Experts talked about the true composition of bottled water, https://rg.ru/2020/05/22/eksperty-rasskazali-ob-istinnom-sostave-butilirovannojvody.html

10. In Russia, from April 1, 2020 to March 1, 2021, an experiment on labeling of packaged water will be carried out, http://www.garant.ru/news/1334562/\#ixzz6NOTGINIP

11. Order of the Government of the Russian Federation of August 27, 2009 No. 1235-r on the approval of the Water Strategy of the Russian Federation for the period up to 2020

12. W.M. Khadra, Journal of Food Composition and Analysis 93, 103609 (2020) https://doi.org/10.1016/j.jfca.2020.103609 